\title{
PEMAKAIAN BAHASA INDONESIA DALAM NOVEL IBUK \\ KARYA IWAN SETYAWAN
}

\author{
Kasno Atmo Sukarto \\ Fakultas Bahasa dan Sastra, Univeritas Nasional \\ Jakarta \\ Pos el: kasnoas@yahoo.com
}

\begin{abstract}
Novel "Ibuk" which was written in Indoesian language tends to use local language particularly Javanese. The javanese exists in the Indonesian written novel is the writer's style. It shows the uniqueness of Novel itself which was written by iwan Setyawan. This article aims at describing elements of javanese in applying Indonesian Language. This article employs descriptive qualitative method, which is describing javanese elements in the novel. The theory of SPEAKING Hymes (1972) was employed to analize the data. The finding shows that there are japanese language in the novel Ibuk include nasalisation, repeated words, root words, and sentences.
\end{abstract}

\begin{abstract}
ABSTRAK
Bahasa Indonesia yang digunakan dalam novel Ibuk ada kecenderungan menggunakan bahasa daerah khususnya bahasa Jawa. Bahasa Jawa yang muncul dalam novel yang berbahasa Indonesia itu merupakan ciri dan gaya penulisnya. Hal itu merupakan keunikan novel Ibuk karya Iwan Setyawan. Tujuan penulisan ini adalah untuk mendeskripsikan unsur-unsur bahasa Jawa dalam pemakaian bahasa Indonesia. Metode penulisan ini adalah metode deskriptif kualitatif yaitu mendeskripsikan unsur-unsur bahasa Jawa dalam pemakaian bahasa Indonesia novel tersebut. Adapun teori yang dipakai untuk mendeskripsikan pemakaian bahasa Jawa mengacu pada teori SPEAKING Hymes (1972). Hasil analisis menunjukkan bahwa terdapat pemakaian bahasa Jawa dalam bahasa Indonesia novel Ibuk meliputi bentuk nasalisasi, kata ulang, kata dasar, dan kalimat.
\end{abstract}

\section{Kata Kunci: Nasalisasi, Kata Ulang, Kata Dasar, Kalimat}

\section{PENDAHULUAN}

Latar Belakang

Bahasa merupakan sarana komunikasi yang sangat penting dalam kehidupan masyarakat. Bahasa juga digunakan sebagai sarana dalam kegiatan aktivitas manusia, misalnya mencakup masalah bahasa seni tari, seni rupa, seni musik, dan seni sastra . Dalam seni sastra misalnya ada novel, cerpen, puisi, dan teks drama, yang kesemuanya itu menggunakan sarana bahasa Indonesia. Dalam penggunakan bahasa Indonesia itu, dan seiring dengan perkembangan zaman selalu mengalami perubahan yag didasari atas keadaan pada masanya.

Bahasa Indonesia yang digunakan dalam novel misalnya juga mengalami perubahan khususnya dalam pemakaian bahasa-bahasa daerah dan termasuk pemakaian bahasa asing dengan sengaja atau tidak sengaja terbawa dalam wacana atau dalam bahasa novel yang telah ditulis oleh pengaranganya. Hal itu misalnya dapat kita lihat dalam novel Ibuk karya Iwan Setiawan yang telah dterbitkan oleh penerbit Gramedia Pustaka Utama, Jakarta pada tahun 2016 ini merupakan novel yang populer. Noel ini penggunaan bahasa Indonesianya mudah dipahami oleh kalagan pembaca. Hanya saja dalam paparan bahasa Indonesia terdapat unsur-unsur bahasa daerah dan bahasa asing. Hal itu dilakukan 
oleh pengarang "barangkali" dalam karyanya sebagai cara untuk memikat pembacanya atau bahkan sebagai ciri-ciri karyanya.

Iwan setyawan dalam novel Ibuk menampilkan gaya bahasa yang sederhana dan mudah dipahami, hanya cirinya adalah menampilkan unsur bahasa Jawa dan Ingrris dalam karyanya itu. Hal itu dilakukan "barangkali" dilatari oleh kemampuan bahasa daerah (Jawa), bahasa Indonesia dialek Betawi, dan bahasa asing (Inggris). itulah yang menjadi unik karya Iwan Setyawan ini. Misalnya saja kata kata seperti Mbok,wis,tah (Jawa), jodohin (Betawi), play boy (Inggris)..Kata -kata seperti itu menghiasi paparan dalam novelnya. Kecenderungan menggunakan bahasa daerah dan bahasa asing itu, merupakan ciri khas Iwan Setyawan dalam novel-novelnya.

Bahasa yang digunakan dalam novelnya adalah cenderung lisan resmi. Kalaupun tidak resmi, memang dalam novel adanya dialok antartokoh. Oleh karena itu, Iwan Setyawan menggunakan bahasa yang "gaul" dalam karyanya dengan harapan agar dapat diminati pembacanya. Dengan kata lain, Iwan Setyawan mempunyai ciri sendiri atas karya-karyanya dengan menempatkan bahasa daerah dan bahasa asing di dalam karyanya itu yang menjadi unik untuk dikaji dan diteliti lebih lanjut.

Penelitian terhadap novel Ibuk ini pernah dilakukan oleh Saudara Lestari mahasiswa Fakultas Bahasa dan Sastra, Program Studi Sastra Indonesia.Tahun 2017. Dalam penelitiannya hanya menekankan pada kajian psikologi tokoh utama dan belum mengkji masalah pengunaan bahasa pengarangnya. Atas dasar iu, penulis ingin melanjutkan untuk meneliti ikhwal penggunaan bahasa Indonesia Iwan Setyawan dalam novel IBuk. Selain itu, bahwa dalam karya sastra khususnya novel banyak yang menerapkan multi bahasa dalam paparan bahasa Indonesia. Hal itulah yang menarik bagi penulis untuk meneliti lebih lanjut novel Ibuk.

\section{Rumusan Masalah}

Berdasarkan latar belakang masalah, rumusan masalah penelitian ini adalah sebagai berikut.

1. Bagaimana ciri ragam bahasa Novel Ibuk karya Iwan Setyawan.

2. Bagaimana pengaruh bahasa Jawa terhadap bahasa Indonesia yang digunakan.

3. Bagaimana bentuk nasalisai, kata dasar, kata ulang, dan kalimat.

\section{Tujuan Penulisan}

Penelitian ini bertujuan mendeskripsikan pemakaian bahasa Indonesia yang digunakan dalam novel Ibuk karya Iwan Setyawan. Adapun ruang lingkup penelitiannya adalah sebagai berikut.

1. Ciri-ciri ragam bahasa yang dipakai dalam novel Ibuk.

2. Unsur bahasa Jawa yang muncul dalam novel Ibuk.

3. Variasi pemakaian kata, frasa, dan kalimat.

\section{Sumber Data}

Sumber data nelitian ini adalah Novel Ibuk Karya Iwan Setyawan,cetakan ketiga, terbit tahun 2017, diterbitkan di Jakarta. Adapun datanya adalah unsur-unsur bahasa daerah khususnya bahasa Jawa yang terdapat dalam novel Ibuk oleh penerbit PT Gramedia Pustaka Utama.

\section{Landasan Teori}

\section{Hakikat Pemakaian Bahasa}

Berbicara tentang pemakaian bahasa dalam konteks kajian ini mengacu pada Kasno (2012: 8) menytakan bahwa bagaimana cara menerapkan dan memilih kosakata (kata) frasa, klausa, dan kalimat dalam sebuah tulisan yang dibuat oleh kalangan redaktur. Dengan kata lain, bahwa cara menerapkan dan 
memilih kosakata bukan hanya diterapkan oleh para redaktur saja melainkan bisa juga diterapkan oleh para pengarang atau sastrawan dalam karya-karyanya. Misalnya dalam novel, puisi, teks drama, atau cerpen. Ketepatan dalam memilih kosakata yang tepat sesuai dengan sasaran pembaca merupakan suatu keterampilan bagi seorang pengarang dalam menciptakan karyanya. Dengan demikian, karyanya akan dapat dipahami oleh pembaca tanpa adanya keraguan dalam menikmati karya sastra yang dibacanya. Dengan tidak secara langsung apabila seorang pengarang dapat menempatkan dan memilih kosakata yang tepat sesuai dengan sasaran pembaca, pembaca akan merasa mendapat suatu pengetahuan dan pengalaman dalam memperoleh kosakata yang belum pernah ia kenal, bahkan belum pernah ia ketahui sama sekali. Seorang pengarang secara bijak akan dapat memilih kosakata yang tepat sesuai dengan ancangannya.

Satu catatan adalah bahwa seorang pengarang yang dapat menguasai lebih dari dua bahasa, ketika sedang berbicara atau sedang menulis suatu karya bahasa yang dikuasi itu akan terbawa dalam bahasa paparan karyanya. Hal itu mengacu pada pandangan Weinreich (1970: 1) dalam Hastuti ( 1995: 10) mengemukakan bahwa interferensi sebagai penyimpangan norma bahasa masing-masing yang terjadi dalam tuturan dwibahasawan akibat pengenalannya terhadap lebih dari satu bahasa. Oleh karena itu, seseorang baik dalam berbicara maupun menulis dalam bahasa Indonesia, maka akan cenderung muncul bahasa lain yang dikuasai itu baik dalam bahasa lisan maupun dalam bahasa tulis.

\section{Ragam Bahasa}

Landasan teori yang digunakan dalam penelitian novel Ibuk ini adalah teori nonstandar Kridalaksana (1992: 3 - 4) yang menyatakan bahwa tentang ragam standar atau baku yang digunakan dalam komunikasi resmi, wacana teknis, pembicaraan di depan umum, dengan orang yang dihormati. dalam kaitan dengan penelitian ini adalah wacana teknis yang khususnya pada karya sastra yaitu novel. Novel yang dimaksud adalah novel Ibuk. Adapun teori yan dipakai untuk mendeskripsikan data adalah teori Hymes (1972) dalam Kasno (2012: 13-14) terdapat delapan komponen peristiwa tutur yakni SPEAKING. Kedelapan komponen itu dapat dijadikan dasar untuk menganalisis pemakaian bahasa di novel Ibuk yaitu pemakaian bahasa Indonesia.

Kedelapan komponen yang diakronimkan SPEAKING, (1) setting and scene ('latar dan suasana tutur'), (2) participant ('peserta tutur'), (3) ends/purpose and goal ('tujuan tutur'), (4) act sequences ( urutan tindak tutur'), (5) keys/tone or spirit of act ('nada tutur'), (6) instrumentalities ('sarana tutur, termasuk jalur pemakaian bahasa'), (7) norm/of interaction and interpretation ('norma-norma bahasa'), dan (8) genre ( jenis tutur).

Setting dan Scene, berkaitan dengan keadaan, suasana, dan situasi pemakaian bahasa tersebut pada waktu dilakuan kontak bahasa. Dalam hal ini interaktif antartokoh tindakan sesuai dengan suasana seperti itu akan memengaruhi tokoh utama dan tokoh bawahan dalam berkomunikasi.

Participant, yaitu peristiwa tutur. Hal ini berlangsung tokoh utama dan tokoh bawahan. Kesepakatan dalam bertindak bahasa seperti pada cakupan ini dipengaruhi oleh kedudukan dan masalah atau topik yang mendasari adanya suatu komunikasi antartokoh .

End/ porpuse and goal, merupakan hasil dan tujuan apa yang telah disepakati oleh tokoh utama dan tokoh bawahan. Oleh karena itu, tindak bahasa seperti ini akan memengaruhi pengarang dalam bentuk-bentuk bahasa yang dipakai dalam berkomunikasi.

Act Sequence, merupakan bentuk isi pesan dan topik yang akan dibicarakan dalam berkomunikasi antartokoh.Topik dan isi pesan itu dapat memengaruhi pengarang 
untuk melakukan pemilihan bentuk bahasa/ ragam bahasa sesuai dengan konteks pembicaraan antartokoh.

Key/tone of spirit of act, merupakan ragam bahasa yang dipakai dalam komunikasi juga akan memengaruhi bentuk-bentuk tuturan antartokoh .

Instrumentalities, yakni menunjukkan adanya tuturan yang akan dipakai dalam berkomunikasi. Cakupan seperti ini yang membias pada ranah karya sastra yang berupa novel.

Norm/of interaction and interpretation, Norma bahasa yang dimaksud di sini adalah etika bahasa atau santun bahasa yang diterapkan oleh seseorang pengarang.

Genre, yaitu berkaitan dengan jenis pesan yang dimaksud misalnya bisa berupa pantun, puisi, dan dialog. Hal semacam ini bisa memengaruhi bentuk-bentuk bahasa yang dipakai.

\section{Kedwibahasaan}

Ikhwal kedwibahasaan mengacu pada pandangan Mackey (1968: 554) yang menyatakan bahwa kedwibahasaan sebagai pemakaian dua bahasa atau lebih oleh seorang penutur. Atas dasar bagi seorang pengarang ketika mencipta sebuah karya sastra, bahasa yang dikuasai akan muncul seketika tanpa disadari. Dengan demikian, ketika sorang pengarang sedang menulis karya sastra (novel), yang timbul dalam karyanya adalah adanya unsur-unsur bahasa Jawa dalam pemakaian bahasa Indonesia. Padahal sebaiknya dan seharusnya memakai bahasa Indonesia secara konsisten. Hal-hal semacam itu akan muncul dalam karya sastra misalnya novel Ibuk karya Iwan Setyawan ini. Akan tetapi, bukan hanya terjadi pada novel-novel saja, melainkan dalam bentuk lain pun akan muncul ketika seseorang terjadi kontak bahasa,baik secara lisan maupun khasan secara tertulis. Hal-hal semacam itu yang menjadi keunikan dan kekhasan dalam sebuah karya sastra, khususnya novel Ibuk karya Iwan Setyawan.

\section{Metode Penelitian}

Penelitian ini dilaksanakan dengan menggunkaan metode deskriptif-kulaitatif yakni mendeskripsikan frekuensi pemakaian interferensi bahasa Jawa dalam pemakaian bahasa Indonesia novel Ibuk karya Iwan Setyawan. Teknik pengolahan data dilakukan dengan cara membaca novel Ibuk sekaligus menandai unsur-unsur bahasa Jawa yang terdapat dalam novel Ibuk. Setelah itu, langkah berikutnya adalah memilah-milah kata dasar, frasa dan kalimat bahasa Jawa yang terdapat dalam novel Ibuk. Langkah berikutnya adalah menganalisis secara terpilih berdasarkan unsur kata dasar, frasa, dan kalimat.

\section{Hasil Analisis}

Pada bagian analiss ini akan dipaparkan tentang analisis data yang diperoleh secara sampel berdasarkan frekuensi pemakaian dalam novel Ibuk. Analisis secra sederhana ini sekurang-kurangnya akan memberi gambaran bahwa setiap novel yang dilatari oleh pengarang yang menguasi lebih dari dua basa, ketika mengarang sebuah karya akan muncul bahasa yang dikuasi dalam karangannya. Misalnya, Iwan Setyawan sangat cerdas dan unik dalam mengolah kosakata memasukkan unsur-unsur bahasa Jawa dalam novel Ibuk.

\section{Nasalisasi}

1. Sekarang aku ikut narik angkot suami kakak angkatku itu. (I/2016/10) 
2. Ginilah hidupku Nah. Tiap hari seperti ini. Dari pagi sampa Minggu lagi ngangkot terus. Demi hidup kata Sim pelan”. (I/2016/19)

3. Aku nglairno anak tanpa tahu bagaimana pendidikan kelak. Bagaimana hidupnya kelak. ( $\mathrm{I} / 2016 / 52)$

4. Kali ini ia memberanikan diri meminta Ibuk. Soal belakang sepatu kirinya nglungkap hamper lepas. (I/2016/59)

Dalam tataran ini pengarang dalam karyanya telah menampilkan paparan bahasa Indonesia, tetapi pada kenyataannya karena kecenderungan pengarang menampilkan paparan bahasa Indonesia masih tersirat adanya unsur bahasa daerah yaitu bahasa Jawa. unsur-unsur bahasa Jawa yang berupa bentuk nasalisasi itu ditampilkan oleh pengarang sekadar sebagai sinonim. Selain itu, jika memakai paparan bahasa Indonesia, dianggap kurang sesuai dengan situasi, sasaran, dan kondisi yang ada. Dengan demikian, unsur-unsur bahasa Jawa masuk dalam tataran bahasa Indonesia dengan pertimbangan sesuai dengan sasaran pembacanya.

Dalam bahasa Indonesia, unsur-unsur leksikal bahasa Jawa yang digunakan pada Kalimat 1 sampai dengan 4 adalah sebagai berikut. 1) narik, 2) ngangkot, 3) nglairno, dan 4) nglungkap. Kata-kata tersebut dalam bahasa Indonesia berpadan dengan menarik, menarik angkot (angkutan kota), melahirkan, dan mengelupas.

\section{Kata Ulang}

1. “Aku Tanya Mbok Pah dulu ya. Ati-ati di Jalan Mas,' Jawab Tiah. (I/2016/13) Dalam tataran ini pengarang dalam karyanya telah menampilkan paparan bahasa Indonesia, tetapi pada kenyataannya karena kecenderungan pengarang menampilkan paparan bahasa Indonesia masih tersirat adanya unsur bahasa daerah yaitu bahasa Jawa. unsur-unsur bahasa Jawa yang berupa bentuk kata ulang itu ditampilkan oleh pengarang sekadar sebagai sinonim. Selain itu, jika memakai paparan bahasa Indoneisa, dianggap kurang sesuai dengan situasi, sasaran, dan kondisi yang ada. Dengan demikian, unsurunsur bentuk ulang bahasa Jawa tidak banyak muncul, tetapi sekurang-kurang bentuk ulang muncul sebagai pemanis dan gaya tarik tersendiri bagi pengarang novel ini.

Kata-kata ati-ati bahasa Jawa itu mempunyai padanan bahasa Indonesia hati-hati.

\section{Kata Dasar}

1. "Jadi kita bisa makan empat sehat lima sempurna tiap hari," tutur Ibuk. "Buk, aku mau imbuh. Empal yang separuh tadi dipotog separuh lag, ya," pinta Bayek.(I/2016/48)

2. “Paaak ... aku rangking loro!” teriak Bayek. (I/2016/64)

3. "Oalah Nah, kerja mulai jam enam pagi, narik penumpang, eh mobil mogok lagi (I/2016/68)

4. “Sik, Buk, aku lagi nanggung ngerjain PR,” Jawab Nani. (I/2016/88)

Dalam tataran ini pengarang dalam karyanya telah menampilkan paparan bahasa Indonesia, tetapi pada kenyataannya karena kecenderungan pengarang menampilkan paparan bahasa Indonesia masih tersirat adanya unsur bahasa daerah yaitu bahasa Jawa. unsur-unsur bahasa Jawa yang berupa bentuk dasar itu ditampilkan oleh pengarang sekadar sebagai sinonim. Selain itu, jika memakai paparan bahasa Indoneisa, dianggap kurang sesuai dengan situasi, sasaran, dan kondisi yang ada. Dengan demikian, unsur- 
unsur bentuk dasar bahasa Jawa banyak muncul, tetapi sekurang-kurang bentuk dasar muncul sebagai ciri pengarang menampilkan bentuk dasar bahasa Jawa yang sebenarnya sudah ada padanan bahasa Indonesia. Bentuk kata dasar itu ditampilkan merupakan gaya tarik tersendiri bagi pengarang novel ini.

Dalam bahasa Indonesia, unsur-unsur leksikal pada konteks tersebut yaitu 1) imbuh, 2) loro, 3) mogok, dan 4) sik. Kata-kata tersebut dalam bahasa Indonesia berpadanan dengan tambah (menambah), dua, tidak berjalan (mogok), sebentar,

\section{Kata Ulang}

1. “Aku Tanya Mbok Pah dulu ya. Ati-ati di Jalan Mas,' Jawab Tiah. (I/2016/13) Dalam tataran ini pengarang dalam karyanya telah menampilkan paparan bahasa Indonesia, tetapi pada kenyataannya karena kecenderungan pengarang menampilkan paparan bahasa Indonesia masih tersirat adanya unsur bahasa daerah yaitu bahasa Jawa. unsur-unsur bahasa Jawa yang berupa bentuk kata ulang itu ditampilkan oleh pengarang sekadar sebagai sinonim. Selain itu, jika memakai paparan bahasa Indoneisa, dianggap kurang sesuai dengan situasi, sasaran, dan kondisi yang ada. Dengan demikian, unsurunsur bentuk ulang bahasa Jawa tidak banyak muncul, tetapi sekurang-kurang bentuk ulang muncul sebagai pemanis dan gaya tarik tersendiri bagi pengarang novel ini.

Kata-kata ati-ati bahasa Jawa itu mempunyai padanan bahasa Indonesia hati-hati.

\section{Kalimat}

1. "Buk, wis luwe iki" teriak Bayek. (I/2016/47)

2. Aku,bukan tak pernah bertanya, opo aku iki ibu sing bertanggung jawab? (I/2016/ 52)

3. "Ah, kamu coba pake buku bekas kakakmu, Yek! Yang penting besok bawa buku dulu. Buku baru nanti saja kalau ada rejeki, ya. Insya Alloh, Ibuk belikan di took buku Pelajar. Sabaro sik, Le!” (I/2016/59)

4. "Uripmu cek gak soro koyok aku, Nduk! (I/2016/73)

5. “Wis ngepel ae, ojo cerewet,kata Baye.(I/2016/75)

6. “Wis, wis sing rukun,” kilah Ibuk. (I/2016/75).

7. "Sing ati-ati yo, Nduk. (I/2016/75)

Dalam tataran ini pengarang dalam karyanya telah menampilkan paparan bahasa Indonesia, tetapi pada kenyataannya karena kecenderungan pengarang menampilkan paparan bahasa Indonesia masih tersirat adanya unsur bahasa daerah yaitu bahasa Jawa. unsur-unsur bahasa Jawa yang berupa bentuk kkalimat itu ditampilkan oleh pengarang sekadar sebagai sinonim. Selain itu, jika memakai paparan bahasa Indoneisa, dianggap kurang sesuai dengan situasi, sasaran, dan kondisi yang ada. Dengan demikian, unsurunsur bentuk kalimat bahasa Jawa banyak muncul, tetapi sekurang-kurang bentuk dasar muncul sebagai ciri pengarang menampilkan bentuk dasar bahasa Jawa yang sebenarnya sudah ada padanan bahasa Indonesia. Kalimat itu ditampilkan merupakan gaya tarik tersendiri bagi pengarang novel ini. 
Dalam bahasa Indonesia, kalaimat bahasa Jawa ini sudah ada padanannya dalam bahasa Indonesia seperi berikut.

1) "Buk, wis luwe iki” teriak Bayek. (I/2016/47)

1a. "Bu, sudah lapar ini" teriak Bayek.

2) Aku,bukan tak pernah bertanya, opo aku iki ibu sing bertanggung jawab? (I/2016/ 52)

2a. "apa saya ini Ibu yang bertanggung jawab?

3) “Ah, kamu coba pake buku bekas kakakmu, Yek! Yang penting besok bawa buku dulu. Buku baru nanti saja kalau ada rejeki, ya. Insya Alloh, Ibuk belikan di took buku Pelajar. Sabaro sik, Le!" (I/2016/59)

3a. "Sabar saja, Nak" (anak laki-laki)

4) "Uripmu cek gak soro koyok aku, Nduk! (I/2016/73)

4a. "Hidupmu kan tidak sengsaraseperti saya, Nak."

5) “Wis ngepel ae, ojo cerewet,kata Baye.(I/2016/75)

5a. "Sudah mengepel saja, jangan cerewet."

6) “Wis, wis sing rukun," kilah Ibuk. (I/2016/75).

6a. “Sudah, sudah yang rukun.” kilah Ibuk.

7) "Sing ati-ati yo, Nduk. (I/2016/75)

7a. "Yang hati-hati ya, Nak" ( anak perempuan)

\section{SIMPULAN DAN SARAN}

\section{Simpulan}

Berdasarkan analisis data pemakaiaan bahasa Indonesia novel Ibuk karya Iwan Setyawan ini dapat disimpulkan seperti berikut. Iwan Setyawan dalam novelnya yang berbahasa Indonesia terdapat unsur-unusr bahasa Jawa seperti pemakaian kata dasar, kata ulang, nasalisasi, dan kalimat.

\section{Saran}

Setelah penulis menganalisis tentang pemakaian bahasa Indonesia novel Ibuk karya Iwan Setyawan ini, ternyata masih banyak hal-hal yang belum diteliti oleh peneliti lain, misalnya masalah unsur bahasa Inggris dalam pemakaian bahasa Indonesia . Selain itu, juga belum diteliti pula masalah alih kode dan campur kode. Untuk itu, selayaknya novel ini perlu diteliti lebih lanjut bagi peminat masalah kebahasaan dalam karya sastra khususnya novel Ibuk. 


\section{DAFTAR PUSTAKA}

Hastuti, Tri Iryani. 1995. Pemakian Bahasa Indonesia dalam Majalah Remaja: Kasus Majalah Hai. Jakarta: Pusat Pembinaan dan Pengembangan Bahasa, Departemen Pendidikan dan Kebudayaan.

Hymes, Dell. 1972. "Model of the Interaction of Language and Social Life" . Dalam Gumperz dan D. Hymes: The Etnography of Communication. New York: Holt Rinehart.

Kasno. 2012." Ragam Bahasa Majalah Remaja: Suatu Anaisis Isi”. Sinopsis Disertasi. Jakarta: Program Pascasarjana, Universitas Negeri Jakarta.

Mackey, William F. 1968. "The Description of Bilingualism”. Dalam J.A. Fishman. Reading in Sociology of Language. The Hague: Mouton.

Kridalaksana, Harimurti. 1992. Pembentukan Kata dalam Bahasa Indonesia. Jakarta: Gramedia Pustaka Utama.

Weinreich, Uriel. 1970. Language in Contact: Finding and Problems. The Hague: Mouton. 